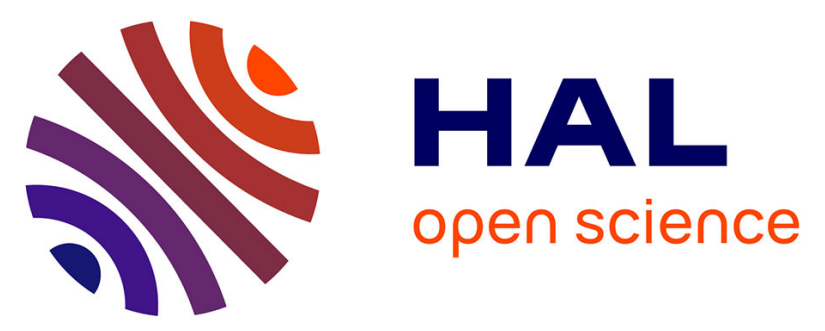

\title{
Escape of water from Mars: study with a ground-to-exosphere global model
}

Francisco González-Galindo, Jean-Yves Chaufray, Franck Lefèvre, Franck

Montmessin, Margaux Vals, Loïc Rossi, Francois, Forget, Ehouarn Millour

\section{- To cite this version:}

Francisco González-Galindo, Jean-Yves Chaufray, Franck Lefèvre, Franck Montmessin, Margaux Vals, et al.. Escape of water from Mars: study with a ground-to-exosphere global model. European Planetary Science Congress. EPSC 2021, Sep 2021, Virtual Meeting, Germany. 10.5194/epsc2021-395 . insu-03321007

\section{HAL Id: insu-03321007 https://hal-insu.archives-ouvertes.fr/insu-03321007}

Submitted on 16 Aug 2021

HAL is a multi-disciplinary open access archive for the deposit and dissemination of scientific research documents, whether they are published or not. The documents may come from teaching and research institutions in France or abroad, or from public or private research centers.
L'archive ouverte pluridisciplinaire HAL, est destinée au dépôt et à la diffusion de documents scientifiques de niveau recherche, publiés ou non, émanant des établissements d'enseignement et de recherche français ou étrangers, des laboratoires publics ou privés.

\section{(c)(1)}

Distributed under a Creative Commons Attribution| 4.0 International License 


\section{Escape of water from Mars: study with a ground-to-exosphere global model}

Francisco González-Galindo ${ }^{1}$, Jean-Yves Chaufray ${ }^{2}$, Franck Lefèvre ${ }^{2}$, Franck Montmessin ${ }^{2}$, Margaux Vals ${ }^{2}$, Loïc Rossi ${ }^{2}$, François Forget ${ }^{3}$, and Ehouarn Millour ${ }^{3}$

${ }^{1}$ Instituto de Astrofísica de Andalucía-CSIC, Granada, Spain (ggalindo@iaa.es)

${ }^{2}$ LATMOS/IPSL, Guyancourt, France

${ }^{3}$ Laboratoire de Météorologie Dynamique/IPSL, Paris, France

The thermal escape of hydrogen from Mars is recognized as one of the major drivers of the longterm climatic evolution of the planet. Recent works have shown that, contrary to what was previously believed, water is not trapped in the lower atmosphere of Mars. Instead, it can be transported to the middle/upper atmosphere, producing layers of supersaturated water (Fedorova et al., 2018, 2021). Upper atmospheric water can then be converted to hydrogen by photolysis or chemical reactions with ions, boosting the rate of hydrogen escape (Chaffin et al., 2017; Stone et al., 2020). Strong seasonal variations in the escape rate, and significant increases of both the water abundance in the mesosphere and the hydrogen escape rate during dust storms, evidence the strong coupling between the hydrogen escape and the water cycle (Chaffin et al., 2014; Fedorova et al., 2018, 2020). A global model able to simulate all the processes related to water, from the ice sublimation to the transport to the upper atmosphere and its atmospheric escape, is needed in order to help interpreting the observations. This model can also be used to explore also the water cycle and hydrogen escape on past Mars conditions characterized by different orbital parameters, allowing for a better estimation of the accumulated escape rate.

Previous simulations with the LMD-Mars Global Climate Model (LMD-MGCM), and their comparison with observational results by SPICAM/Mars Express showed that the simulated escape rate was underestimated, in particular during the second half of the Martian year (Chaufray et al., 2021). However, those simulations did not take into account the microphysical processes producing water supersaturation, and thus underestimated the role of water transport in the escape rate. In addition, the model did not include the photochemistry of water-derived ions, which can play an important role in converting water into hydrogen (Stone et al., 2020).

New simulations with an improved version of the LMD-MGCM have been produced that overcome those previous limitations. The water cloud microphysics has now been fully considered in the simulations, using the model by Navarro et al. (2014). The photochemical model has been updated to include water-derived ions $(\mathrm{H} 2 \mathrm{O}+, \mathrm{H} 3 \mathrm{O}+, \mathrm{OH}+)$. Also, the deuterium fractionation model has been improved (Rossi et al., 2021), and deuterated species have been included in the photochemical model. While this last modification is not expected to modify the hydrogen escape rate, the inclusion of deuterated species can provide important diagnostics on the hydrogen escape and its accumulation over Mars history. 
In this presentation we will show the results of the improved version of the LMD-MGCM, comparing with available observations. The focus will be on the predicted hydrogen escape rate, and how it is affected by the inclusion of different physical processes. We find that including the possibility of water supersaturation increases the Hydrogen escape rate in more than one order of magnitude at most seasons, taking the simulated rate to better agreement with SPICAM observations during the second half of the year. This confirms previous observational results indicating the importance of water supersaturation (Fedorova et al. 2020). We also find that the inclusion of water-derived ions in the photochemistry also increases the escape rate, in particular during the first part of the year. We will also compare the predicted water abundance in the mesosphere with Mars Express and ExoMars TGO observations, and the abundances of water-derived ions with NGIMS/MAVEN measurements.

\section{References:}

Chaffin, M. et al., Unexpected variability of Martian hydrogen escape, Geophysical Research Letters, Volume 41, pp. 314-320 (2014)

Chaffin, M. et al., Elevated atmospheric escape of atomic hydrogen from Mars induced by highaltitude water, Nature Geoscience, 10, pp. 174-178 (2017)

Fedorova, A. et al., Water vapor in the middle atmosphere of Mars during the 2007 global dust storm, Icarus, 300, pp. 440-457 (2018)

Fedorova, A. et al., Stormy water on Mars: The distribution and saturation of atmospheric water during the dusty season, Science, 367, pp. 297-300 (2020)

Fedorova, A. et al., Multi-Annual Monitoring of the Water Vapor Vertical Distribution on Mars by SPICAM on Mars Express, Journal of Geophysical Research: Planets, 126, e06616 (2021)

Navarro, T. et al., Global climate modeling of the Martian water cycle with improved microphysics and radiatively active water ice clouds, Journal of Geophysical Research: Planets, 119, pp. 1479-1495 (2014)

Rossi, L. et al., The Effect of the Martian 2018 Global Dust Storm on HDO as Predicted by a Mars Global Climate Model, Geophysical Research Letters, 48, e90962 (2021)

Stone, S. et al., Hydrogen escape from Mars is driven by seasonal and dust storm transport of water,Science, 370, pp. 824-831 (2020) 